\title{
The 64th Calorimetry Conference Special Issue
}

\author{
Joseph A. Rard
}

Published online: 28 October 2010

(C) Springer Science+Business Media, LLC 2010

The Calorimetry Conference first met in 1946 and has held yearly meetings since then, either in the United States or in Canada. Whenever the IUPAC Conference on Chemical Thermodynamics (ICCT) is held in either of these two countries then a joint meeting is held with the Calorimetry Conference. Several histories have been written about the Calorimetry Conference covering its first 25 years [1] and its first 50 years [2, 3].

In the earliest Calorimetry Conferences there was an emphasis on developing standard materials to allow for inter comparison of results from calorimeters at different laboratories and to improve the methods and equipment used for such measurements. The Calorimetry Conferences now cover a wide range of topics involving calorimetry and thermodynamics within the disciplines of biology, chemistry (including pharmaceuticals and polymers), physics, engineering, materials science, interdisciplinary areas, and new instrumentation.

The 64th Calorimetry Conference (CALCON 2009) was held at the Santa Fe Hilton Historic Plaza, in Santa Fe, New Mexico from June 28 to July 2, 2009. The Conference Chair was David P. Remeta (Rutgers University), the Program Chair Michael T. Henzl (University of Missouri), and the Local Arrangements Chair Conceição A.S.A. Minetti (Rutgers University) who is also the Secretary-Treasurer. This is the third Calorimetry Conference held in the beautiful city of Santa Fe.

The following symposia were held at CALCON 2009 (including their organizers), which illustrates both the wide range of topics covered and the level of international participation: Biothermodynamics: Macromolecular Recognition, Function, and Stability (Michael T. Henzl, University of Missouri, USA; Conceição A.S.A. Minetti; Rutgers University, USA; David P. Remeta, Rutgers University, USA); Condensed Matter Physics and Detectors (Jason Lashley, Los Alamos National Laboratory, USA; Akira Inaba, Osaka University, Japan); Pharmaceutical Applications (Simon Gaisford, University of London, United Kingdom; Michael O’Neill, Aston University, United Kingdom); Polymer Thermodynamics

J.A. Rard $(\bowtie)$

4363 Claremont Way, Livermore, CA 94550, USA

e-mail: solution_chemistry2@comcast.net 
(Michael Frenkel, National Institute of Standards and Technology, Boulder, USA; JeanPierre Grolier, Université Blaise Pascal, France); Solutions and Fluid Mixtures (Joseph A. Rard, Livermore, California, USA); and Thermodynamic Databases, Modeling, and Simulations (Vincent Shen, National Institute of Standards and Technology, Gaithersburg, USA).

I attended my first Calorimetry Conference in 1984 where, at this and an immediately preceding conference, I met my current joint editor Earle Waghorne. At a later Calorimetry Conference I met my previous joint editor Donald A. Palmer. The Calorimetry Conferences provide great venues to meet scientists actively involved in thermodynamic research, including many major figures in solution chemistry.

I am fortunate to have attended eleven of the Calorimetry Conferences, including CALCON 2009. This includes the 52nd Calorimetry Conference held in 1997 at the Asilomar Conference Center in Pacific Grove, California, where I was the Local Arrangements Chair. I have been unable to attend many conferences in recent years, especially since retiring from Lawrence Livermore National Laboratory in 2007. It was therefore a great pleasure to be invited to organize a symposium at CALCON 2009, and I am especially grateful to David P. Renata and the other officers of the Calorimetry Conference for their encouragement and support that allowed me to attend.

This issue contains a selection of papers based on research presented at CALCON 2009, including a very thorough review of fluid state heat capacities by Emmerich Wilhelm that was presented as the Plenary Lecture at the symposium on Solutions and Fluid Mixtures. Three additional papers are based on lectures presented at this symposium, and an additional one is based on a lecture presented at a session on Proteins and Protein-Ligand Interactions. Two papers also contributed to this issue are by authors of a talk presented at this conference, but who presented preliminary results in a different subject area.

\section{References}

1. Stull, D.R., Sinke, G.C.: History of the calorimetry conference 1946-1970. Bull. Thermodyn. Thermochem. 14, 445-485 (1971)

2. Izatt, R.M., Brown, P.R., Oscarson, J.L.: The history of the calorimetry conference: 1946-1995. J. Chem. Thermodyn. 27, 449-464 (1995)

3. Domalski, E.S., Goldberg, R.N., O'Hare, P.A.G.: Conference report: 50th calorimetry conference Gaithersburg, MD, July 23-28, 1995. J. Res. Nat. Inst. Stand. Technol. 101, 63-68 (1996) 